\title{
18. Increasing Interest in the Economic Determinants of Structural, Technological and Climate Change
}

\author{
Jim Butler
}

Perhaps the most succinct definition of economics is that it is the science of scarcity. This is an abbreviation of the fuller definition provided by Lionel Robbins in the 1930s as 'the science which studies human behaviour as a relationship between ends and scarce means which have alternative uses' (Robbins 1932, 15). While these definitions appear to be clear and concise, they belie deeper philosophical issues around the nature of the discipline which have been, and continue to be, debated by scholars. For example, Robbins viewed economics as a positive science that concerns itself with understanding facts and analysing 'what is' as opposed to a science that concerns itself also with normative issues, with the value judgments that underlie economists' policy prescriptions, and with arguments about 'what ought to be'. An example of a more recent contrary view of science in general, and economics in particular, is provided by Boldeman (2007).

Notwithstanding these deeper recurring issues, the succinct definition of economics as the science of scarcity serves the useful purpose of locating it as a science which studies phenomena that involve scarcity-and few would dispute that. In terms of change, then, the changes with which economics concerns itself are those associated with the problem of scarcity. Such changes are manifold and vary considerably through time. In the UK in the first half of the nineteenth century, the introduction of the Corn Laws, which imposed heavy import duties on imported grain (thereby increasing the price of bread), occupied the minds of a number of economists. In numerous countries the twenty-first century presents a different set of challenges, including the development of markets for human tissue, body parts and surrogates for human reproduction, and the problem of rationing scarce geostationary orbit slots for the placement of satellites. ${ }^{1}$ But these changes all have, as their underlying bedrock, the common theme of striving to satisfy more wants of humankind with the limited resources at our disposal.

\footnotetext{
1 A geostationary orbit of a satellite is one that results in the satellite orbiting the Earth above the equator at a speed matching the Earth's rotation, thus appearing to remain stationary. Most communications satellites are in geostationary orbit.
} 
Observing that economics, as the science of scarcity, is interested in change from that point of view is a very broad beginning to a chapter on economics and change. After all - at the risk of being platitudinous - scarcity and change are both ubiquitous, so this starting point could be construed as an argument that economists are interested in everything! So how might this enquiry be narrowed to cast more light on how economics deals with change?

To begin, consider the following question: Of the multitude of changes that have occurred and will continue to occur in society, are there particular types of change that are of enduring interest to economists? While it is not the purpose of this chapter to fully develop a typology of change for this purpose, some interesting insights can be gained by considering the broad types of change that have consistently occupied the minds of economists regardless of time and place.

Investigation of these broad types begins by turning to The new Palgrave dictionary of economics, a major and authoritative work first published in 1987 with the second edition appearing in $2008 .^{2}$ The online version of the dictionary allows both editions to be searched for the word 'change' in article titles across all topics in the dictionary. The results of this search are shown in Table 1. The overlap between the types of change appearing in article titles across the various editions of the dictionary is clear: 'structural change' and 'technical/ technological change' feature in a number of titles in both editions. 'Agricultural growth and population change' has disappeared, and 'climate change' is a new entry, in the $2008+$ editions.

Table 1: New Palgrave dictionary articles with 'change' in the article title.

\begin{tabular}{|c|c|}
\hline 1987 edition & $2008+$ editions $^{(a)}$ \\
\hline $\begin{array}{l}\text { 1. Structural change } \\
\text { 2. Technical change } \\
\text { 3. Agricultural growth and population } \\
\text { change } \\
\text { 4. Biased and unbiased technological } \\
\text { change }\end{array}$ & $\begin{array}{l}\text { 1. Structural change } \\
\text { 2. Technical change } \\
\text { 3. Skill-based technical change } \\
\text { 4. Structural change, econometrics of } \\
\text { 5. Climate change, economics of } \\
\text { 6. Biased and unbiased technological change }\end{array}$ \\
\hline
\end{tabular}

(a) Includes the 2008 edition plus all new articles included in the dictionary since then.

To illustrate how economics approaches these types of changes, attention in the remainder of this chapter will focus on structural change, technological change, and climate change.

2 The first edition comprised four volumes, and the second eight volumes. The original Palgrave's dictionary of political economy comprised three volumes and was first published in 1894. Palgrave was 'a banker and one-time editor of The Economist whose avocation was economics' (Stigler 1988, p.1729). 


\section{Structural change}

Structural change, also sometimes referred to as structural transformation, refers to large-scale changes in the composition of industries in an economy. Traditionally, economics has distinguished between primary industries (such as agriculture, fishing, forestry, mining), secondary industries (manufacturing and construction) and tertiary industries (services). It has been observed over a long period that, as economic development occurs, economies tend to undergo structural change, moving away from a predominant reliance on primary industries as the source of a nation's wealth to secondary and tertiary industries. The industrial revolution which began in Great Britain in the second half of the eighteenth century, and subsequently spread to Western Europe and the US, is testimony to this. The works of Fisher (1939) and Clark (1940) are two examples of this argument concerning economic development and structural change.

Two features of how economics deals with structural change are of interest here. The first, which leads to a theme that recurs in later discussion, relates to how the discipline has changed its approach to understanding structural change. Matsuyama (2008) argues that the earlier literature on this subject 'is mostly descriptive, trying to provide a sweeping overview of the development process, with the emphasis on the multifaceted nature of structural change'. He goes on to argue that 'recent work tends to be more analytical, using formal models designed to focus on a few specific aspects of structural change'. This shift from a descriptive to an analytical focus reflects an attempt to gain a deeper understanding of the causal connection between economic development and structural change. Having observed an association between the two, what is the causal relationship between them-if any? Does economic development cause structural change by creating a major shift in the pattern of demand for goods and services? Does structural change cause economic development to occur because it reflects major increases in productivity brought about by innovation and invention? Or does causality run in both directions, a possibility mentioned by Matsuyama (2008): 'There is also an increasing awareness that the two-way causality between economic growth and structural change can provide possible explanations for development failures.' Finally, it is possible that both occur simultaneously but are not causally connected, being driven by some other underlying causal factor common to both.

The second feature of interest arising out of how economics deals with structural change is the growing realisation that the conventional threefold classification of industries (primary, secondary, tertiary) is itself in need of change in that it needs to be augmented with a fourth category -information-/knowledgebased industries. Spawned by developments in information technology and discoveries in other new fields such as biotechnology, these new industries 
generate wealth by using information and knowledge to generate further innovation and inventive activity. Drucker $(1969,12)$, in his book The age of discontinuity, argues:

Technologically, the established 'modern' industries may still enjoy a long period of growth and advance ... But in their ability to provide the thrust for further substantial growth of the developed economies, they are mature, if not stagnant.

This brings us to the second major type of change that warrants discussiontechnological change, itself a major contributor to structural change and a new fourth category of industries.

\section{Technological change}

The production function is a central concept in economics, showing the relationship between the quantities of inputs used in producing a product (or service) and the maximum output of that product attainable from those quantities of inputs. The production function, so defined, is based upon a given technology for transforming inputs into outputs. Technological change occurs when that transformation process changes. By and large, technological changes are of interest when they enable more output to be achieved with any quantity of inputs-referred to as cost-reducing technological changes because they reduce the cost of producing products. As the science of scarcity, economics is interested in cost-reducing technological change because it enables us to make more efficient use of limited resources.

Technological change is an important determinant of economic growth. It has played a major role in structural change in the economy, and is responsible for many improvements in production processes and consequentially increases in productivity and national income. It stands to reason, therefore, that economists would be interested in the determinants of the rate of technological change. However, for many years, technological change was assumed by economists to be exogenous, that is, it was assumed that its determinants were non-economic in nature, and were therefore outside the economic system and not amenable to economic analysis. This was particularly evident in growth theory, where economists concentrated on the role of physical quantities of inputs in the production function in generating higher output rather than on the nature of the input-output transformation process - the technology - embodied in the production function. Thus, for example, differences in growth rates between countries were seen as being due to differences in their resource endowmentscountries with higher growth rates tended to have relatively greater resource endowments. When technology was recognised as playing a role, for example, 
in the models of economic growth developed by Solow (1956) and Swan (1956) in which technology was the mechanism by which a country could continue growing despite the law of diminishing returns, it was assumed to be exogenous.

The assumption of exogenous technological change was also invoked in an industry-specific context even when the pace of such change was a major feature of the industry. In the healthcare industry, for example, which has experienced rapid technological change, it is only more recently that economists have begun to study the determinants of the rate of technological change in healthcare more seriously. This is notwithstanding the conclusion by Newhouse (1992) that technological change in healthcare was responsible for well over half of the increase in expenditures on medical care over a 50-year period in the US.

In both of these areas - economic growth and health care - more recent work in economics has sought to treat the rate of technological change as endogenous, that is, as being determined by economic factors within the system. Endogenous growth theory makes the determinant of the rate of technological change internal to the economic system by allowing firms to earn monopoly rents from research activities that result in the production of new knowledge. These research activities generate new knowledge because they lead to investment in human capital. The enhancement of a nation's human capital will lead to economic growth by leading to the development of new forms of technology and efficient and effective means of production. ${ }^{3}$ In healthcare, researchers have hypothesised that the rate of technological change is endogenous to the health insurance system. With widespread health insurance in many countries, patients face relatively low or even zero out-of-pocket expenses for many healthcare services. Therefore patients, and doctors acting on their behalf, have little incentive to reject new technologies even if their health impact is small because the patient's financial exposure is very limited or zero. Knowing that their products will be sold into heavily insured markets, firms in the healthcare sector have a stronger incentive to invest in research and development relative to firms in other industries. These features were incorporated into a model of insurance and innovation in medical care by Goddeeris (1984) who also showed that insurance results in technological change that is less cost-reducing or more cost-increasing than in other industries.

As seen with structural change, economists working on technological change have made concerted attempts to improve understanding of the causes of such change. This interest in causality reflects a determination not to simply accept

3 Aghion and Howitt (2009) provide an overview of growth theory in economics including endogenous growth theory. 
and describe change, but to understand its economic determinants. Our third type of change of significance to economics - climate change - also demonstrates this characteristic.

\section{Climate change}

As economics is a social science, economists' work on climate change has grown commensurately with the increasing acceptance by climate scientists of the anthropogenic cause theory of climate change. The essence of this theory is that, by generating increasing emissions of greenhouse gases (especially carbon dioxide), human behaviour is causing a long-term increase in global surface temperatures.

Economists' interest in this topic is motivated by what Hardin (1968) referred to, in the title of his famous paper, as the tragedy of the commons. The 'commons' refers to common property resources - resources which do not have defined private property rights but which are owned by society in common. This lack of property rights allows individuals to use such resources without paying any access fee because there is no defined owner of the resource. As a consequence, individuals can overexploit such resources in the sense that they can harvest them beyond the point where the marginal value of the resource to them is equal to the marginal cost imposed upon society at large by their exploitation. This often results in degradation of the quality of the resource and, if utilisation is sufficiently high, can also lead to its disappearance. For example, in the absence of property rights over the fish in the sea, overharvesting can lead to reduction in fish stocks and eventually to their extinction; in the absence of property rights for geostationary orbits in space, overcrowding can result in degradation of service quality in telecommunications because of the proximity of neighbouring satellites; and in the absence of property rights in inner and outer space, gases from humankind's activity can accumulate in the earth's atmosphere to levels that potentially adversely affect life on earth.

In principle, the solution to the tragedy of the commons would seem to be the creation of property rights in common property resources, thus allowing their use to be governed by a functioning market or by some form of regulatory apparatus. For both technical and political reasons, this can be difficult-on the latter, witness the difficulties in arriving at international agreements on the management of climate change.

The remainder of this chapter focuses on two particular facets of economics and climate change. The first, which is not unique to how economics interacts with climate science but is usefully illustrated by it, is how economists deal with uncertainty and debates regarding the validity of scientific hypotheses 
advanced by other scientists. The economist qua economist has no particular knowledge or expertise in climate science so relies on the state of the art as enunciated by experts in that field. Where consensus or near-consensus has been achieved in that field, the economic assessment of various options for reducing or preventing anthropogenic climate change, mitigating its effects and adapting to its existence can proceed with some confidence. The magnitudes of the costs and benefits associated with these options can be estimated within reasonable bounds and sound policy advice can be formulated.

While there now appears to be a wide consensus on both the existence of, and anthropogenic cause of, global warming, uncertainty continues to exist about the magnitude of the effect of carbon dioxide emissions on global temperatures and the downstream effects on economies. The effect of this uncertainty on the work undertaken by economists was highlighted in earlier work by Nordhaus (1982, 242): 'Depending on the scenario, the effect of a $\mathrm{CO}_{2}$ doubling ranged from minus 12 percent of global GNP to plus 5 percent. These are clearly very large impacts, but they are also very uncertain.' Narrowing this uncertainty has proved to be a difficult task. A recent article in The Economist entitled 'Climate science: a sensitive matter', published on 30 March 2013, ${ }^{4}$ states: 'The climate may be heating up less in response to greenhouse-gas emissions than was once thought.' This assessment is based on work by climate scientists who found 'surface temperatures since 2005 are already at the low end of the range of projections derived from 20 climate models'.

The second facet of economics and climate change of interest in this chapter is the parallel development of thinking with respect to causes of change in the two sciences. The economist's growing interest in endogenous causes of technological change has already been discussed above. In their entry on climate change in The new Palgrave dictionary of economics, Goulder and Pizer (2008) refer to this in the context of climate change: 'Climate change is an inherently long-term problem and assumptions about technological change are particularly important. The modelling of technological change has advanced significantly beyond the early tradition that treated technological change as exogenous.'

How does this parallel the development of thinking in climate science with respect to the causes of climate change? For many years, society has regarded weather and climate-related events as being acts of God-changes that were outside the control of humans. The concept of an event being an act of God also plays an important role in the law of contracts where a defendant can invoke act of God as a defence against an action for breach of contract, and in the insurance industry where ideally the event to be insured against (such as damage to crops)

4 www.economist.com/news/science-and-technology/21574461-climate-may-be-heating-up-less-responsegreenhouse-gas-emissions (accessed 2 June 2014). 
is outside the control of the insured individual or organisation. While the language of climate science does not express the anthropogenic cause theory of climate change as being a search for endogenous causes of climate change, the concept underlying that theory parallels the economists' search for what this discipline labels endogenous causes. At this level of discourse, economists' increasing interest in endogenous causes of change shares the climate scientists' view of climate change as being endogenous to human behaviour and not entirely an act of God.

\section{Conclusion}

As with other sciences, both natural and social, economics is concerned with the causes and consequences of change. Of particular interest in this discipline are changes that impinge upon the problem of scarcity and human ability to address that problem with limited resources. The main theme of this chapter is that, over the last half century, economists have become increasingly interested in understanding the causes of change. For too long, the intellectual convenience of assuming causes of change to be exogenous to the economic system and to humankind itself have held sway. The growing interest in endogenous causes of change holds the promise of deepening our understanding of how to improve the welfare of society by broadening the array of possible instruments available to achieve that goal. This development in economics is argued to parallel a similar development in climate science which itself has become heavily involved in research on endogenous causes of climate change. Perhaps this trend reflects a growing interest in human behaviour as an important cause of changes in nature and society - maybe humankind causes change, thereby influencing our own destiny, more than we previously thought?

\section{References}

Aghion, P and Howitt, PW (2009) The economics of growth. MIT Press, Cambridge MA.

Boldeman, L (2007) The cult of the market: economic fundamentalism and its discontents. ANU E Press, Canberra.

Clark, C (1940) The conditions of economic progress. Macmillan, London.

Drucker, PF (1969) The age of discontinuity: guidelines to our changing society. Harper and Row, New York. 
Fisher, A (1939) Production, primary, secondary and tertiary. Economic Record 15(1): 24-38.

Goddeeris, JH (1984) Insurance and incentives for innovation in medical care. Southern Economic Journal 51(2): 530-9.

Goulder H and Pizer, WA (2008) Climate change, economics of. In Durlauf, SN and Blume, LE (eds) The new Palgrave dictionary of economics. 2nd ed. Palgrave Macmillan, London, www.palgravemacmillan.com.au/palgrave/ onix/isbn/9780333786765 (online version used).

Hardin, C (1968) The tragedy of the commons. Science (New Series), 162(3859): 1243-8.

Matsuyama, K (2008) Structural change. In Durlauf SN and Blume LE (eds) The new Palgrave dictionary of economics. 2nd ed. Palgrave Macmillan, London, www.palgravemacmillan.com.au/palgrave/onix/ isbn/9780333786765 (online version used).

Newhouse, JP (1992) Medical care costs: how much welfare loss? Journal of Economic Perspectives 6(3): 3-21.

Nordhaus, W (1982) How fast should we graze the global commons? American Economic Review 72(2): 242-6.

Robbins, L (1932) An essay on the nature and significance of economic science. Macmillan, London.

Solow, RM (1956) A contribution to the theory of economic growth. Quarterly Journal of Economics 70(1): 65-94.

Stigler, GJ (1988) Palgrave's dictionary of economics. Journal of Economic Literature 26(4): 1729-36.

Swan, TW (1956) Economic growth and capital accumulation. Economic Record 32(2): 334-61. 
This text is taken from Change! Combining Analytic Approaches with Street Wisdom, edited by Gabriele Bammer, published 2015 by ANU Press, The Australian National University, Canberra, Australia. 